\title{
PENERAPAN METODE SMALL GROUP DISCUSSION (SGD) UNTUK MENINGKATKAN PEMAHAMAN DAN APLIKASI PEMBELAJARAN BERBASIS MASALAH BAGI GURU SDN 1 GUNUNGSARI MAESAN BONDOWOSO
}

\author{
Rini Fatanah \\ SDN Gunungsari 1 Maesan Bondowoso Indonesia \\ rinifatanah@gmail.com
}

\begin{abstract}
The purpose of this study was to improve the understanding and ability of teachers in applying the Problem-Based Learning (PBM) model with the Small Group Discussion (SGD) method. The research method used is classroom action research which is carried out in two cycles. The data collection technique was carried out by collecting the results of the study showing that the assessment of the practice of implementing learning in the classroom using the Problem-Based Learning (PBM) model before the research was carried out got a score of 59 with poor criteria. Then it increased in cycle 1 to 70 with quite good criteria. In the second cycle, it continued to increase to 90 with very good criteria. The results of the increase in teacher products in preparing lesson plans (RPP) using the Problem-Based Learning model, from before the research the average was 56 with poor criteria, in cycle 1 actions became 78 with good criteria and cycle 2 became 89 with very good criteria. . While the increase in the assessment of learning practices in the classroom in mathematics using the Problem-Based Learning model from before the research was an average of 59 with poor criteria, in the first cycle of action it became 83 with very good criteria and cycle 2 of 89 with very good criteria.
\end{abstract}

Keywords: Small Group Discussion method, teacher understanding, problem-based learning

Abstrak: Tujuan penelitian ini adalah untuk meningkatkan pemahaman dan kemampuan guru dalam mengaplikasikan model Pembelajaran Berbasis Masalah (PBM) dengan Metode Small Group Discussion (SGD). Metode penelitian yang digunakan adalah penelitian tindakan kelas yang dilaksanakan dua siklus. Teknik pengumpulan data dilakukan dengan mengumpulkan Hasil penelitian menunjukkan bahwa penilian terhadap praktek pelaksanaan pembelajaran di kelas dengan menggunakan model Pembelajaran Berbasis Masalah (PBM) sebelum dilakukan penelitian mendapat nilai sebesar 59 dengan kriteria kurang baik. Kemudian meningkat pada siklus 1 menjadi 70 dengan kriteria cukup baik. Pada siklus kedua terus meningkat menjadi 90 dengan kriteria sangat baik. Hasil peningkatan terhadap produk guru dalam menyusun rencana pelaksanaan pembelajaran (RPP) dengan menggunakan model Pembelajaran Berbasis Masalah, dari sebelum penelitian rata-rata 56 dengan kriteria kurang baik, pada tindakan siklus 1 menjadi 78 dengan kriteria baik dan siklus 2 menjadi 89 dengan kriteria sangat baik. Sedangkan peningkatan pada penilaian praktek pembelajaran di kelas pada pelajaran matematika dengan menggunakan model Pembelajaran Berbasis Masalah dari sebelum penelitian ratarata 59 dengan kriteria kurang baik, pada tindakan siklus 1 menjadi 83 dengan kriteria sangat baik dan siklus 2 sebesar 89 dengan kriteria sangat baik

Kata kunci: metode Small Group Discussion, pemahaman guru, pembelajaran berbasis masalah 


\section{PENDAHULUAN}

Lampiran Peraturan Menteri Pendidikan Dasar (Permendiknas) RI No. 22 Tahun 2006, menyebutkan bahwa, dalam setiap kesempatan pembelajaran matematika hendaknya dimulai dengan pengenalan masalah yang sesuai dengan situasi (contextual problem). Lebih lanjut dikemukakan dalam salah satu tujuan mata pelajaran matematika adalah: "Memecahkan masalah yang meliputi kemampuan memahami masalah, merancang model matematika, menyelesaikan model dan menafsirkan solusi yang diperoleh". Sementara itu, dalam Permendiknas nomor 16 tahun 2007 tentang standar kualifikasi akademik dan kompetensi guru. Secara garis besar permen tersebut berisi 4 kompetensi inti guru yaitu: kompetensi pedagogik, sosial, kepribadian, dan profesional. Pada kompetensi profesional untuk guru SD mengandung tuntutan diantaranya adalah menerapkan berbagai pendekatan,model, strategi, metode, dan teknik pembelajaranyang mendidik secara kreatif. Pada kompetensi pedagogik mengandung tuntutan diantaranya pada pembelajaran matematika guru SD mampu menggunakan matematisasi horizontal dan vertikal untuk menyelesaikan masalah matematika dan masalah dalam dunia nyata, dan mampu menggunakan pengetahuan konseptual, prosedural, dan keterkaitan keduanya dalam pemecahan masalah matematika, serta penerapannya dalam kehidupan seharihari. Hal tersebut diperkuat dengan Permendiknas RI No. 41 tahun 2007 yang menyebutkan bahwa proses pembelajaran pada setiap satuan pendidikan dasar dan menengah harus interaktif, inspiratif, menyenangkan, menantang, dan memotivasi peserta didik untuk berpartisipasi aktif serta memberikan ruang yang cukup bagi prakarsa, kreativitas dan kemandirian sesuaidengan bakat, minat, dan perkembangan fisik serta psikologis peserta didik.

Menurut Surur \& Tartilla (2019) untuk mengembangkan kemampuan pemecahan masalah siswa, diperlukan perbaikan dan inovasi pada proses Pembelajaran Berbasis Masalah yang dianggap dapat digunakan untuk mengatasi masalah terkait hasil belajar tanpa selalu cenderung berfokus kepada guru.

Namun kenyataan di sekolah pada umumnya dan khususnya pada guru di SDN Gunungsari 1 kecamatan Maesan kabupaten Bondowoso, masih banyak mengalami kesulitan atau kendala untuk melaksanakan Pembelajaran Berbasis Masalah. Hal tersebut karena sebagian mereka masih kesulitan untuk mendapatkan 
informasi tentang pengertian masalah dan strategi pemecahan masalah beserta contoh-contohnya. Sesuai dengan hasil wawancara yang dilakukan oleh kepala sekolah menyebutkan bahwa mayoritas guru masih kesulitan dalam menerapkan model pembalajaran berbasis masalah (PBM) pada pelajaran matematika. Hal ini sesuai dengan pengakuan guru tentang respon siswa pada saat pembelajaran matematika dengan menggunakan model pembelajaran masalah (PBM) rata-rata siswa terlihat kurang aktif, proses pembelajarannya kurang semangat dan masih terlihat lesu dengan tingkat ketuntasan belajar siswa masih rendah. Dari hasil wawancara tersebut ternyata guru mengatakan bahwa rata-rata guru masih kesulitan dalam membuat masalah sebagai bahan untuk dipecahkan yang sesuai dengan materi pembelajaran dan mengarahkan siswa untuk aktif mengadakan penyelidikan dan kesulitan dalam menerapkan Pembelajaran Berbasis Masalah (PBM) pada pelajaran matematika.

Hasil wawancara tersebut juga diperkuat oleh hasil observasi yang telah dilakukan kepala sekolah ditemukan bahwa pemahaman guru dalam merancang atau menyusun rencana pelaksanaan pembelajaran atau (RPP) khususnya pada pelajaran matematika dengan menggunakan model Pembelajaran Berbasis Masalah (PBM) masih sangat rendah. Hasil observasi sebelum dilakukan penelitian terhadap produk guru tersebut dapat dijelaskan dalam tabel 1 sebagai berikut.

Tabel 1 Hasil penilaian produk guru (RPP) dengan menggunakan model Pembelajaran Berbasis Masalah (PBM) sebelum penelitian

\begin{tabular}{clcc}
\hline No & \multicolumn{1}{c}{ Uraian Kegiatan } & Skor & Nilai \\
\hline 1 & $\begin{array}{l}\text { Kesesuaian antara rancangan situasi masalah dengan } \\
\text { tujuan pembelajaran }\end{array}$ & 14 & 58 \\
\hline 2 & $\begin{array}{l}\text { Kualitas rancangan situasi masalah yang akan } \\
\text { diselesaikan siswa }\end{array}$ & 13 & 54 \\
\hline 3 & $\begin{array}{l}\text { Kesesuaian antara rancangan situasi masalah dengan } \\
\text { pengorganisasian sumberdaya dan rencana logistik }\end{array}$ & 14 & 58 \\
\hline $\begin{array}{l}\text { Kesesuaian antara rancangan situasi masalah dengan } \\
\text { rancangan teknik dan prosedur penilaian hasil } \\
\text { belajar yang akan diterapkan }\end{array}$ & 12 & 50 \\
\hline 5 & $\begin{array}{l}\text { Kesesuaian antara rancangan situasi masalah dengan } \\
\text { langkah-langkah pembelajaran }\end{array}$ & 13 & 54 \\
\hline \multicolumn{1}{c}{ Jumlah skor } & 66 & 274 \\
\hline Skor maksimal & 120 & 500 \\
\hline & Rata-rata & 56 \\
\hline
\end{tabular}




\begin{tabular}{ll}
\hline Kriteria & Kurang baik \\
\hline
\end{tabular}

Dari hasil observasi seperti pada tabel 1 diatas terhadap rencana pelaksanaan pembelajaran (RPP) dengan menggunakan model Pembelajaran Berbasis Masalah (PBM) sebelum dilakukan penelitian rata-rata 56 dengan kriteria kurang baik.

Hasil observasi terhadap praktek pelaksanaan pembelajaran di kelas dengan dengan menggunakan model Pembelajaran Berbasis Masalah (PBM) dapat dijelaskan dalam tabel 2 sebagai berikut.

Tabel 2 Hasil penilaian praktek pembelajaran di kelas dengan menggunakan model Pembelajaran Berbasis Masalah (PBM) sebelum penelitian

\begin{tabular}{|c|c|c|c|}
\hline No & Uraian Kegiatan & Skor & Nilai \\
\hline \multicolumn{4}{|c|}{ Pendahuluan } \\
\hline 1 & Orientasi pada masalah & 15 & 63 \\
\hline \multicolumn{4}{|l|}{ Inti } \\
\hline 2 & Mengorganisasi siswa untuk belajar & 14 & 58 \\
\hline 3 & $\begin{array}{l}\text { Membimbing penyelidikan individual } \\
\text { maupun kelompok }\end{array}$ & 15 & 63 \\
\hline 4 & $\begin{array}{l}\text { Mengembangkan dan menyajikan hasil } \\
\text { karya }\end{array}$ & 13 & 54 \\
\hline \multicolumn{4}{|c|}{ Penutup } \\
\hline 5 & $\begin{array}{l}\text { Menganalisis dan mengevaluasi proses } \\
\text { pemecahan masalah }\end{array}$ & 13 & 54 \\
\hline & Jumlah Skor & 70 & 292 \\
\hline & Skor maksimal & 120 & 500 \\
\hline & Rata-rata & \multicolumn{2}{|c|}{59} \\
\hline & Kriteria & \multicolumn{2}{|c|}{ Kurang baik } \\
\hline
\end{tabular}

Dari hasil observasi seperti pada tabel 2 diatas terhadap praktek pelaksanaan pembelajaran di kelas dengan menggunakan model Pembelajaran Berbasis Masalah (PBM) sebelum dilakukan penelitian rata-rata 59 dengan kriteria kurang baik.

Berdasarkan hasil observasi di atas dapat diketahui bahwa perlu ada penerapan pendekatan inovatif untuk mencapai tujuan pembelajaran. Salah satu pendekatan yang dapat memenuhi tuntutan tersebut adalah Pembelajaran Berbasis Masalah. 
Dalam proses pembelajaran Matematikan diutamakan kemampuan pemecahan masalah, agar siswa terdorong untuk berpikir intensif dan kreatif dalam menyelesaikan masalahnya (Elita et al., 2019). Kemampuan pemecahan masalah memiliki makna sebuah kecakapan mengorganisasikan konsep, fakta, dan menghubungkan pengetahuan yang dimiliki sebelumnya, serta menggunakan keterampilan penalaran untuk memecahkan masalah (Arta et al., 2020). Tahaptahap dalam memecahkan masalah, yaitu mampu mengartikan permasalahan, menyusun skema solusi, mengimplemetasikan skema tersebut, dan meninjau ulang proses yang telah dibuat. Dalam pembelajaran matematika berbasis masalah ini, siswa dituntut untuk dapat memecahkan masalah yang meliputi kemampuan memahami masalah, merancang model matematika, menyelesaikan model dan menafsirkan solusi yang diperoleh. Permasalahan-permasalahan yang diberikan hendaknya dibuat sedemikian rupa hingga memberi peluang dan merangsang siswa untuk menguji ide/dugaan dengan caranya sendiri. Selain itu penyelesaian permasalahan dilakukan secara kelompok yang terdiri atas 2 sampai dengan 4 siswa sehingga siswa dapat berlatih untuk meningkatkan sikap kerjasama dengan sesama teman sejawat, membantu dalam kerja kelompok, menghargai pendapat teman, tukar pengalaman, dan keberanian bertanya (Mawaddah \& Anisah, 2015). Langkah-langkah dalam pembelajaran Problem Based Learning (PBL), disajikan guru sebagai berikut: a) orientasi siswa pada masalah; b) guru membimbing siswa untuk membentuk kelompok yang beranggotakan 5-6 orang siswa secara heterogen; c) guru membagi Lembar Kerja Siswa (LKS) pada setiap kelompok; d) siswa mengumpulkan informasi yang sesuai, siswa bersama kelompoknya melakukan eksperimen untuk mendapatkan penjelasan dan pemecahan masalah; e) guru membantu siswa dalam menyiapkan hasil dari percobaan; f) guru membimbing siswa untuk melakukan presentasi; g) guru membimbing siswa untuk melakukan evaluasi (Tyas, 2017). Aktifitas pembelajaran PBL akan dipadukan dengan metode Small Group Discussion (SGD) yang merupakan diskusi kelompok kecil berbasis tutorial dimana siswa bersama tutor berupaya memahami dan mencari solusi permasalahan yang telah disajikan untuk mencapai tujuan pembelajaran. Menurut Fitria et al. (2013) Langkah-langkah penerapan metode SGD menggunakan 5 jump diantaranya:1) Membagi kelas menjadi beberapa 
kelompok kecil (maksimal 5 mahasiswa) dengan menunjuk ketua dan sekretaris; 2) mengidentifikasi kata yang sulit dan menjawab; 3) Mengidentifikasi masalah yang akan didiskusikan; 4) menjawab masalah sementara; 5) menetapkan tujuan pembelajaran; 6) mencari jawaban dari tujuan pembelajaran. Manfaat kegiatan SGD antara lain mampu meningkatkan ketrampilan komunikasi, mendorong mahasiswa dalam ketrampilan pemecahan masalah, meningkatkan belajar mandiri dan bertukar informasi, menerima umpan balik dari guru dan antar anggota.

Berdasarkan latarbelakang tersebut penulis ingin mengetahui tingkat pemahaman dan keberhasilan guru dalam penerapan model Pembelajaran Berbasis Masalah (PBL) dengan metode Small Group Discussion (SGD).

\section{METODE}

Metode yang digunakan pada penelitian ini adalah metode penelitian sekolah. Penelitian dilaksanakan dengan menerapkan tindakan yang mengacu pada skenario metode Small Group Discussion (SGD) dengan langkah-langkah sebagai berikut.

a. Perencanaan

Tindakan yang akan diambil dalam penelitian tindakan sekolah (PTS) ini dengan menggunakan metode small group discussion (SGD), dengan rencana tindakan sebagai berikut.

- Peneliti merumuskan permasalahan secara operasional, relevan dengan rumusan masalah penelitian.

- Peneliti merumuskan hipotesis tindakan

- Merencanakan pembelajaran yang akan diterapkan dalam tindakan penelitian.

- Menentukan program penyajian.

- Mengembangkan skenario penyajian.

- Menyiapkan sumber dan media pembelajaran.

- Menyusun alat evaluasi.

- Mengembangkan format penilaian.

- Mengembangkan format observasi/ angket. 
b. Pelaksanaan

Pada kegiatan pelaksanaan penelitian terdapat dua tindakan yaitu tindakan 1 berupa tindakan pertemuan dengan guru dan tindakan 2 berupa praktek pembelajaran di kelas. Langkah-langkah tindakan yang digunakan pada siklus 1 tindakan ke 1 adalah sebagaiberikut.

- Kepala sekolah membagi kelas menjadi beberapa kelompok guru.

- Kepala sekolah memberikan soal studi kasus sesuai dengan materi yang mau dibahas.

- Kepala sekolah menginstruksikan setiap kelompok guru untuk mendiskusikan jawaban soal tersebut.

- Kepala sekolah membimbing tiap kelompok guru untuk berpartisipasi aktif dalam diskusi.

- Kepala sekolah membimbing setiap kelompok guru untuk menyajikan hasil diskusinya.

- Kepala sekolah mengklarifikasi, penyimpulan dan tindak lanjut.

c. Observasi

Mencatat temuan-temuan yang ada selama kegiatan yaitu observasi terhadap dampak diterapkan metode small group discussion (SGD) dengan menggunakan lembar observasi yang telah disiapkan peneliti sebelumnya ataupun catatan langsung dalam pengamatan.

d. Refleksi

- Melakukan evaluasi terhadap hasil temuan-temuan selama kegiatan.

- Melakukan pertemuan untuk mendiskusikan dengan teman sejawat tentang temuan-temuan yang diperoleh dalam kegiatan.

- Melakukan revisi untuk perbaikan pada siklus selanjutnya (siklus 2)

Subjek penelitian ini adalah Guru SDN Gunungsari 1 kecamatan Maesan kabupaten Bondowoso tahun pelajaran 2017/2018 yang berjumlah enam guru kelas I-VI. Terkait dengan analisis pemahaman guru tentang Pembelajaran Berbasis Masalah matematika maka digunakanlah instrumen pengumpulan data berupa observasi, wawancara dan produk guru.

a. Wawancara 
Dalam penelitian ini, peneliti menggunakan instrumen berupa daftar pertanyaan sebagai pedoman wawancara untuk dianalisis terhadap pendapat guru tentang pemahaman guru terhadap Pembelajaran Berbasis Masalah matematika sebelum dilakukan tindakan ataupun sesudah dilakukan tindakan.

b. Produk guru

Penilaian produk guru diisi oleh kepala sekolah berdasarkan produk yang dihasilkan oleh guru. Produk guru berupa rencana pelaksanaan pembelajaran (RPP) pada Pembelajaran Berbasis Masalah matematika.

\section{c. Observasi}

Kegiatan pengamatan atau observasi dilakukan terhadap 2 aspek yaitu pengamatan terhadap kepala sekolah dan pengamatan terhadap aktifitas guru selama kepala sekolah melakukan tindakan.

Pengumpulan data

Data yang diperlukan ini adalah hasil observasi pada aktivitas guru pada saat kegiatan tindakan dan aktifitas kepala sekolah selaku peneliti dan penilaian terhadap praktek pembelajaran di kelas dan produk yang dihasilkan melalui kegiatan. Kemudian dari hasil tersebut dianalisis menggunakan rubrik penilaian. Untuk mendapatkan data yang diperoleh peneliti menggunakan langkah-langkah sebagai berikut:

a) Menyediakan perangkat observasi beserta rubrik yang diperlukan.

b) Memberikan lembar kerja keseluruhan subjek penelitian

c) Mengumpulkan lembar lembar kerja yang telah dikerjakan guru.

d) Mengidentifikasi hasil kerja guru berdasarkan rubrik yang telah di tentukan.

e) Menghitung skor produk setiap guru/subjek penelitian dengan menggunakan rumus :

$$
S=\frac{R}{N} \times 100
$$

Keterangan rumus :

$\mathrm{S}=$ Nilai yang dicari ( sesuai dengan aspek masing-masing )

$\mathrm{R}=$ Jumlah skor dari item yang dianggap benar.

$\mathrm{N}=$ Skor maksimum dari tes tersebut

Teknik analisis data 
Untuk menganalisis data pada penelitian ini, peneliti menggunakan tehnik statistik deskriptif kuantitatif. Kegiatan yang terpenting dalam pelaksanaan analisis data adalah mengelolah skor menjadi nilai. Adapun tahap analisisnya adalah sebagai berikut.

a) Menyusun tabel frekuensi untuk tiap-tiap indikator

b) Menghitung mean ( $M$ ) dengan rumus.

$$
M=\frac{F x}{n}
$$

Keterangan :

$$
\begin{aligned}
& M=\text { mean } / \text { nilai rata-rata } \\
& F=\text { frekuensi } \\
& X=\text { nilai } \\
& n=\text { jumlah guru. }
\end{aligned}
$$

c) Sedangkan untuk menganalisis data observasi menggunakan tabel 3 sebagai berikut:

\begin{tabular}{cll}
\hline No & \multicolumn{1}{c}{ Nilai } & \multicolumn{1}{c}{ Kriteria } \\
\hline 1 & $81-100$ & Sangat baik \\
\hline 2 & $71-80$ & Baik \\
\hline 3 & $61-70$ & Cukup baik \\
\hline 4 & Kurang dari 60 & Kurang baik \\
\hline
\end{tabular}

Indikator keberhasilan

Penelitian tindakan sekolah (PTS) dimaksudkan untuk meningkatkan pemahaman guru dalam Pembelajaran Berbasis Masalah matematika, maka dari itu keberhasilan penelitian tindakan ini ditandai dengan adanya peningkatan pemahaman guru ke arah yang lebih baik. Indikator keberhasilan pada penelitian ini, secara kuatitatif ditandai dengan adanya peningkatan produk guru dalam membuat rencana pelaksanaan pembelajaran (RPP) dan hasil penilian terhadap pelaksanaan pembelajaran di kelas secara individu guru $\geq 81$ dengan kriteria sangat baik. 


\section{HASIL PENELITIAN DAN PEMBAHASAN}

\section{Aktifitas Kepala Sekolah/Peneliti}

Dari hasil pengamatan yang dilakukan oleh observer terhadap aktifitas kepala sekolah pada tindakan siklus 1 dapat dijelaskan pada table 4 sebagai berikut.

Tabel 4 Hasil observasi aktifitas kepala sekolah Siklus 1

\begin{tabular}{|c|c|c|}
\hline NO & Hal yang diobservasi & Skor \\
\hline 1 & Menyampaikan tujuan yang ingin dicapai & 3 \\
\hline 2 & $\begin{array}{l}\text { Memberikan materi dan mengkaitkannya dengan masalah } \\
\text { yang dibahas }\end{array}$ & 3 \\
\hline 3 & $\begin{array}{l}\text { Menggali pengetahuan awal guru dengan melakukan } \\
\text { tanyajawab. }\end{array}$ & 2 \\
\hline 4 & $\begin{array}{l}\text { Menyediakan media untuk digunakan dalam menyelesaikan } \\
\text { masalah dalam. }\end{array}$ & 3 \\
\hline 5 & $\begin{array}{l}\text { Mengorganisasi guru kedalam kelompok kecil yang terdiri } \\
\text { dari 1-3 guru yang hetreogen. }\end{array}$ & 3 \\
\hline 6 & $\begin{array}{l}\text { Memberikan kesempatan pada guru untuk melakkan diskusi } \\
\text { dalam kelompok. }\end{array}$ & 2 \\
\hline 7 & $\begin{array}{llll}\text { Memberikan kesempatan } & \text { pada } & \text { guru } & \text { untuk } \\
\text { mempresentasikan hasil diskusi. } & & & \\
\end{array}$ & 2 \\
\hline 8 & Memberikan penghargaan kepada kelompok terbaik. & 2 \\
\hline 9 & $\begin{array}{l}\text { Memberikan kesempatan pada guru untuk bertanya dan } \\
\text { memberikan refleksi. }\end{array}$ & 2 \\
\hline \multirow[t]{5}{*}{10} & Membimbing guru menyimpulkan hasil kegiatan. & 3 \\
\hline & Jumlah skor & 25 \\
\hline & Skor maksimal & 30 \\
\hline & Rata-rata & 83 \\
\hline & Kriteria & $\begin{array}{c}\text { Sangat } \\
\text { baik }\end{array}$ \\
\hline
\end{tabular}

Hasil observasi pada aktifitas kepala sekolah pada tindakan siklus 1 seperti pada tabel 4 rata-rata 83 dengan kriteria sangat baik.

\section{Aktifitas Guru}

Hasil pengamatan terhadap aktifitas guru dalam tindakan siklus 1 dapat dijelaskan pada tabel 5 sebagai berikut.

Tabel 5 Hasil rekapitulasi hasil penilaian aktifitas guru siklus 1

\begin{tabular}{clcc}
\hline No & \multicolumn{1}{c}{ Aspek penilaian guru } & Skor & Rata-rata \\
\hline 1 & Kesiapan mental dan fisik guru & 18 & 75 \\
\hline 2 & Kesiapan bahan & 16 & 67 \\
\hline
\end{tabular}




\begin{tabular}{cccc}
\hline No & Aspek penilaian guru & Skor & Rata-rata \\
\hline 3 & Tanggungjawab & 16 & 67 \\
\hline 4 & Diskusi (berfikir bersama) & 16 & 67 \\
\hline 5 & Interaksi (bertanya) & 18 & 75 \\
\hline \multirow{2}{*}{ Jumlah skor tercapai } & 84 & 351 \\
\hline Skor maksimal & 120 & 500 \\
\hline Rata-rata & \multicolumn{2}{c}{70} \\
\hline Kriteria & \multicolumn{2}{c}{ Cukup Baik }
\end{tabular}

Berdasarkan lima aspek pada tabel 5 diatas, didapatkan persentase aktifitas guru pada kegiatan siklus 1 adalah 70 dengan kriteria cukup baik.

\section{Hasil Penilaian Produk Guru}

Hasil penilaian produk guru berupa rencana pelaksanaan pembelajaran (RPP) pada kegiatan siklus 1, dapat dijelaskan pada tabel 6 sebagai berikut.

Tabel 6 Rekapitulasi hasil penilaian produk guru berupa RPP

\begin{tabular}{clcc}
\hline No & \multicolumn{1}{c}{ Aspek penilaian guru } & Skor & Rata-rata \\
\hline 1 & Identitas mata pelajaran & 17 & 71 \\
\hline 2 & Perumusan indikator & 19 & 79 \\
\hline 3 & Perumusan Tujuan Pembelajaran & 19 & 79 \\
\hline 4 & Pemilihan materi ajar & 19 & 79 \\
\hline 5 & Pemilihan sumber belajar & 22 & 92 \\
\hline \multicolumn{2}{c}{ Jumlahskor tercapai } & 96 & 400 \\
\hline Skor maksimal & 120 & 500 \\
\hline Rata-rata & \multicolumn{2}{c}{78} \\
\hline & Kriteria & \multicolumn{3}{c}{ Baik } \\
\hline
\end{tabular}

Berdasarkan hasil penilaian terhadap rencana pelaksanaan pelaksanaan pembelajaran (RPP) siklus 1 seperti pada tabel 6 diatas, dari lima aspek penilaian rata-rata dari lima aspek penilaian sebesar 78 dengan kriteria Baik. Kekurangan yang ditemukan pada produk guru tersebut antara rancangan situasi masalah yang dibuat guru dengan tujuan pembelajaran yang ingin dicapai sudah sesuai namun rancangan situasi masalah yang dibuat guru sedikit kurang singkron dengan kata kerja pada indikator pencapaian kompetensi yang terdapat rencana pelaksanaan pembelajaran (RPP). Kekurangan yang tampak dari kualitas rancangan situasi masalah yang akan diselesaikan siswa sudah baik, namun hanya mengukur 
kompetensi pengetahuan yang mudah saja. Pada aspek rancangan situasi masalah dengan pengorganisasian sumberdaya dan rencana logistik, tampak bahwa rancangan situasi masalah yang dibuat guru kurang disesuaikan dengan sumberdaya yang ada dimiliki sekolah dan rencana pembaiayaannya. Sedangkan pada aspek prosedur penilaian yang digunakan pada rencana pelaksanaan pembelajaran (RPP) masih sedikit kurang sesuai dengan rancangan situasi masalah sedikit kurang lengkap.

\section{Hasil Penilaian Terhadap Pelaksanaan Pembelajaran Di Kelas}

Hasil penilaian terhadap praktek pembelajaran di kelas dengan menerapkan Pembelajaran Berbasis Masalah matematika pada siklus 1 dapat dijelaskan pada tabel 7 sebagaiberikut.

Tabel 7 Rekapitulasi hasil penilaian praktek pembelajaran di kelas siklus 1

\begin{tabular}{clcc}
\hline No & \multicolumn{1}{c}{ Aspek penilaian guru } & Skor & Rata -rata \\
\hline 1 & Mengorientasikan siswa pada situasi masalah & 21 & 88 \\
\hline 2 & Mengorganisasi siswa untuk belajar & 21 & 88 \\
\hline 3 & $\begin{array}{l}\text { Membimbing penyelidikan individual maupun } \\
\text { kelompok }\end{array}$ & 21 & 88 \\
\hline 4 & Mengembangkan dan menyajikan hasil karya & 20 & 83 \\
\hline 5 & $\begin{array}{l}\text { Menganalisis dan mengevaluasi proses } \\
\text { pemecahan masalah }\end{array}$ & 17 & 71 \\
\hline \multicolumn{2}{c}{ Jumlahskor tercapai } & 100 & 418 \\
\hline Skor maksimal & 120 & 500 \\
\hline Rata-rata & \multicolumn{2}{c}{ Sangat baik } \\
\hline \multicolumn{2}{c}{ Kriteria }
\end{tabular}

Dari tabel 7 diatas dapat di jelaskan bahwa hasil penilaian terhadap praktek pelaksanaan pembelajaran di kelas pada siklus 1 rata-rata 83 dengan kriteria sangat baik. Pemaparan diatas menunjukkan bahwa hasil observasi terhadap aktifitas kepala sekolah pada tindakan siklus 1 sudah sangat baik dengan hasil penilaian rata-rata sebesar 83. Sedangkan hasil aktifitas guru pada tindakan siklus 1 rata-rata 70 dengan kriteria cukup baik.

Beberapa kelebihan yang ditemukan pada aktifitas guru, bahwa rata-rata guru memilki kesiapan mental dan fisik guru sebelum dilakukan tindakan yang baik, hal ini ditandai dengan berbagai tampilan guru yang cukup percaya diri dan 
ceria. Kesiapan mental dan kesehatan fisik guru berpengaruh dalam mewujudkan pembelajaran inovatif untuk mencapai tujuan pembelajaran (Sukirman \& Hidayati, 2020). Pada aspek interaksi atau bertanya selama kegiatan diskusi juga sudah nampak baik, hal ini ditandai dengan antusiasme guru pada masing-masing kelompok untuk melakukan diskusi dan saling bertanya kepada teman guru maupun kepada kepala sekolah ketika menemui masalah. Menurut Sari (2017) metode pembelajaran SGD ini dapat mendorong pola pikir kreatif dalam pemecahan suatu masalah, meningkatkan aktifitas dalam menanggapi hasil diskusi kelompok.

Kekurangan yang ditemukan dalam kegiatan refleksi ini bahwa aktifitas guru kurang memiliki kesiapan bahan yang diperlukan dalam kegiatan diskusi juga kelihatan guru tidak membawa peralatan yang diperlukan seperti silabus, alat tulis dan laptop. Tanggungjawab yang masih kelihatan kurang maksimal dalam kegiatan diskusi adalah guru masih belum maksimal dalam memberikan penjelasan pada tiap kelompok yang belum menguasai materi. Indikasi kekurangan yang nampak pada diskusi (berfikir bersama guru) guru belum melibatkan anggota kelompok dalam pemecahan masalah.

\section{Siklus 2}

Hasil pengamatan yang dilakukan oleh observer terhadap aktifitas kepala sekolah pada tindakan siklus 2 dapat dijelaskan pada table 10 sebagai berikut.

Tabel 10 Hasil observasi aktifitas Kepala Sekolah pada Siklus 2

\begin{tabular}{cllc}
\hline NO & \multicolumn{1}{c}{ Hal yang diobservasi } & Skor \\
\hline 1 & Menyampaikan tujuan yang ingin dicapai & 3 \\
\hline 2 & $\begin{array}{l}\text { Memberikan materi dan mengkaitkannya dengan } \\
\text { masalah yang dibahas }\end{array}$ & 3 \\
\hline 3 & $\begin{array}{l}\text { Menggali pengetahuan awal guru dengan } \\
\text { melakukan tanyajawab. }\end{array}$ & 3 \\
\hline 4 & $\begin{array}{l}\text { Menyediakan media untuk digunakan dalam } \\
\text { menyelesaikan masalah dalam . }\end{array}$ & 3 \\
\hline 5 & $\begin{array}{l}\text { Mengorganisasi guru kedalam kelompok kecil } \\
\text { yang terdiri dari 1-3 guru yang hetreogen . }\end{array}$ & 3 \\
\hline 6 & $\begin{array}{l}\text { Memberikan kesempatan pada guru untuk } \\
\text { melakkan diskusi dalam kelompok. }\end{array}$ & 2 \\
\hline 7 & $\begin{array}{l}\text { Memberikan kesempatan pada guru untuk } \\
\text { mempresentasikan hasil diskusi. }\end{array}$ & 3 \\
\hline 8 & $\begin{array}{l}\text { Memberikan penghargaan kepada kelompok } \\
\text { terbaik. }\end{array}$ & 2 \\
\hline
\end{tabular}




\begin{tabular}{clcc}
\hline NO & Hal yang diobservasi & Skor \\
\hline 9 & $\begin{array}{l}\text { Memberikan kesempatan pada } \\
\text { bertanya dan memberikan refleksi. }\end{array}$ & 3 \\
\hline 10 & Membimbing guru menyimpulkan hasil kegiatan. & 3 \\
\hline Jumlah skor & 28 \\
\hline Skor maksimal & 30 \\
\hline Rata-rata & 93 \\
\hline Kriteria & $\begin{array}{c}\text { Sangat } \\
\text { baik }\end{array}$ \\
\hline
\end{tabular}

Hasil observasi pada aktifitas kepala sekolah pada tindakan siklus 2 seperti pada tabel 10 mendapatkan nilai rata-rata 93 dengan kriteria sangat baik.

Hasil pengamatan terhadap aktifitas guru dalam tindakan siklus 2 dapat dijelaskan pada tabel 11 sebagai berikut.

Tabel 11 Hasil rekapitulasi hasil penilaian aktifitas guru siklus 2

\begin{tabular}{clcc}
\hline No & \multicolumn{1}{c}{ Aspek penilaian guru } & Skor & Rata-rata \\
\hline 1 & Kesiapan mental dan fisik guru & 21 & 88 \\
\hline 2 & Kesiapan bahan & 22 & 92 \\
\hline 3 & Tanggungjawab & 22 & 92 \\
\hline 4 & Diskusi (berfikir bersama) & 21 & 88 \\
\hline 5 & Interaksi (bertanya) & 22 & 92 \\
\hline \multirow{2}{*}{ Jumlah skor tercapai } & 108 & 452 \\
\hline Skor maksimal & 120 & 500 \\
\hline Rata-rata & \multicolumn{2}{c}{90} \\
\hline Kriteria & \multicolumn{2}{c}{ Sangat Baik }
\end{tabular}

Berdasarkan lima aspek pada tabel 11 diatas, didapatkan persentase aktifitas guru pada kegiatan siklus 2 adalah 90 dengan kriteria sangat baik.

Hasil penilaian rencana pelaksanaan pembelajaran (RPP) pada kegiatan siklus 2 dapat dijelaskan pada tabel 12 sebagai berikut.

Tabel 12 Rekapitulasi hasil penilaian rencana pelaksanaan pembelajaran (RPP) siklus 2

\begin{tabular}{clccc}
\hline No & \multicolumn{2}{c}{ Aspek penilaian guru } & Skor & $\begin{array}{c}\text { Rata- } \\
\text { rata }\end{array}$ \\
\hline 1 & $\begin{array}{l}\text { Kesesuaian antara rancangan situasi masalah dengan } \\
\text { tujuan pembelajaran }\end{array}$ & 21 & 88 \\
\hline 2 & $\begin{array}{l}\text { Kualitas rancangan } \\
\text { diselesaikan siswa }\end{array}$ & situasi masalah yang akan & 23 & 96 \\
\hline
\end{tabular}




\begin{tabular}{clcc}
\hline No & \multicolumn{1}{c}{ Aspek penilaian guru } & Skor & $\begin{array}{c}\text { Rata- } \\
\text { rata }\end{array}$ \\
\hline 3 & $\begin{array}{l}\text { Kesesuaian antara rancangan situasi masalah dengan } \\
\text { pengorganisasian sumberdaya dan rencana logistik }\end{array}$ & 21 & 88 \\
\hline $\begin{array}{l}\text { Kesesuaian antara rancangan situasi masalah dengan } \\
\text { rancangan teknik dan prosedur penilaian hasil belajar } \\
\text { yang akan diterapkan }\end{array}$ & 22 & 92 \\
\hline 5 & $\begin{array}{l}\text { Kesesuaian antara rancangan situasi masalah dengan } \\
\text { langkah-langkah pembelajaran }\end{array}$ & 20 & 83 \\
\hline Jumlahskor tercapai & 107 & 447 \\
\hline Skor maksimal & 120 & \multicolumn{2}{c}{800} \\
\hline Rata-rata & \multicolumn{2}{c}{ Sangat Baik } \\
\hline Kriteria
\end{tabular}

Berdasarkan hasil penilaian terhadap rencana pelaksanaan pelaksanaan pembelajaran (RPP) siklus 2 seperti pada tabel 12 diatas, dari lima aspek penilaian rata-rata dari lima aspek penilaian sebesar 89 dengan kriteria sangat baik .

Hasil penilaian terhadap praktek pembelajaran di kelas dengan menerapkan Pembelajaran Berbasis Masalah matematika pada siklus 2 dapat dijelaskan pada tabel 13 sebagaiberikut.

Tabel 13 Rekapitulasi hasil penilaian praktek pembelajaran di kelas siklus 2

\begin{tabular}{clcc}
\hline No & \multicolumn{1}{c}{ Aspek penilaian guru } & Skor & $\begin{array}{c}\text { Rata - } \\
\text { rata }\end{array}$ \\
\hline 1 & $\begin{array}{l}\text { Mengorientasikan siswa pada situasi } \\
\text { masalah }\end{array}$ & 23 & 96 \\
\hline 2 & Mengorganisasi siswa untuk belajar & 23 & 96 \\
\hline 3 & $\begin{array}{l}\text { Membimbing penyelidikan individual } \\
\text { maupun kelompok }\end{array}$ & 21 & 88 \\
\hline 4 & $\begin{array}{l}\text { Mengembangkan dan menyajikan hasil } \\
\text { karya }\end{array}$ & 24 & 100 \\
\hline 5 & $\begin{array}{l}\text { Menganalisis dan mengevaluasi proses } \\
\text { pemecahan masalah }\end{array}$ & 20 & 83 \\
\hline$\quad$ Jumlahskor tercapai & 111 & 463 \\
\hline Skor maksimal & 120 & 500 \\
\hline Rata-rata & \multicolumn{2}{c}{89} \\
\hline Kriteria & \multicolumn{2}{c}{ Sangat baik }
\end{tabular}

Dari tabel 13 diatas dapat di jelaskan bahwa hasil penilaian terhadap praktek pelaksanaan pembelajaran di kelas pada siklus 2 rata-rata 89 dengan kriteria sangat baik. Hasil penilaian tertinggi pada aspek mengembangkan dan menyajikan 
hasil karya rata-rata 100 dengan kriteria sangat baik. Sedangkan hasil penilaian terendah pada aspek menganalisis dan mengevaluasi proses pemecahan masalah rata-rata sebesar 83 dengan kriteria sangat baik.

Pada kegiatan siklus 2 guru sudah memiliki kesiapan bahan yang diperlukan dalam kegiatan diskusi juga, guru sudah membawa peralatan yang diperlukan seperti silabus, alat tulis dan laptop. Dalam kegiatan diskusi guru sudah mulai perhatian kepada teman guru dengan peduli untuk memberikan penjelasan pada tiap kelompok yang belum menguasai materi. Pada diskusi (berfikir bersama guru) guru sudah melibatkan anggota kelompok dalam pemecahan masalah.

Hasil penilaian terhadap produk guru berupa rencana pelaksanaan pembelajaran (RPP) dengan menggunakan model Pembelajaran Berbasis Masalah matematika pada tindakan siklus 2 rata-rata 89 dengan kriteria sangat baik. Hasil penilaian menunjukkan bahwa semua aspek penilaian pada produk guru sudak berhasil disusun dengan sangat baik. Pada kegiatan siklus 2 produk guru tersebut antara rancangan situasi masalah yang dibuat guru dengan tujuan pembelajaran yang ingin dicapai sudah sesuai dan singkron dengan kata kerja pada indikator pencapaian kompetensi yang terdapat rencana pelaksanaan pembelajaran (RPP). Kualitas rancangan situasi masalah yang akan diselesaikan siswa sudah dengan mengukur kompetensi pengetahuan yang baik yang mudah maupun yang sulit. Pada aspek rancangan situasi masalah dengan pengorganisasian sumberdaya dan rencana logistik sudah disesuaikan dengan sumberdaya yang ada dimiliki sekolah dan rencana pembaiayaannya. Sedangkan pada aspek prosedur penilaian yang digunakan pada rencana pelaksanaan pembelajaran (RPP) sudah sesuai dengan rancangan situasi masalah.

Hasil wawancara dilakukan pada akhir siklus 2 dengan berpedoman pada daftar pertanyaan berjumlah 5 butir pertanyaan yang telah dibuat peneliti pertanyaan pertama yaitu tingkat pemahaman guru tentang model Pembelajaran Berbasis Masalah (PBM) setelah dilakukan tindakan oleh kepala sekolah. Guru tersebut mengatakan bahwa rata-rata guru sudah paham tentang cara menerapkan pembelajaran masalah matematika, baik dalam menyusun rencana pelaksanaan pembelajaran (RPP) maupun dalam menerapkan model Pembelajaran Berbasis 
Masalah matematika pada praktek pembelajaran di kelas. Hasil jawaban guru tersebut berbeda ketika sebelum dilakukan penelitian. Sebelum dilakukaan peneltian guru mengatakan bahwa guru belum paham dengan Pembelajaran Berbasis Masalah matematika. Beliau hanya tahu tentang penerapan model Pembelajaran Berbasis Masalah pada pelajaran yang lain seperti IPA, IPS, dan lain sebagainya.

Pertanyaan kedua tentang pengertian masalah dalam matematika. Hasil wawancara, menjelaskan bahwa masalah dalam matematika apabila ada pertanyaan pada soal matematika menunjukkan adanya suatu tantangan (challenge) yang tidak dapat dipecahkan dengan prosedur rutin (routine procedure) yang sudah diketahui si pelaku. Hasil jawaban guru tersebut berbeda ketika sebelum dilakukan penelitian. Sebelum dilakukaan peneltian guru mengatakan bahwa semua pertanyaan yang sulit dijawab oleh siswa maka itu disebut sebagai masalah.

Pertanyaan ke tiga tentang cara mengajarkan soal-soal yang penyelesaiannya memerlukan prosedur yang tidak biasa gur ajarkan dalam setiap harinya. Hasil jawaban guru tersebut mengatakan bahwa guru menjelaskan kembali prosedur dasarnya, kemudian mengajak siswa untuk melakukan kegiatan nalar dan peragaan sesuai dengan soal tersebut. Hasil jawaban guru tersebut berbeda ketika hasil wawancara sebelum dilakukan penelitian rata-rata guru mengatakan bahwa guru hanya menjelaskan kembali prosedur dasarnya, kemudian memberikan soal yang serupa untuk menyelesaikannya.

Pertanyaan ke empat tentang prosedur yang biasa di gunakan guru dalam menyelesaiakan masalah matematika. Hasil jawaban guru tersebut mengatakan bahwa rata-rata guru mengajarkan dengan menggunakan prosedur (1) memahami masalah; (2) membuat model matematika; (3) menyelesaikan masalah, dan; (4) menafsirkan solusinya. Hasil jawaban guru tersebut berbeda ketika hasil wawancara sebelum dilakukan penelitian rata-rata guru hanya mengajarkan rumusnya dan mencari jawabannya.

Pertanyaan ke lima tentang kendala dalam menerapkan model Pembelajaran Berbasis Masalah (PBM). Hasil jawaban guru mengatakan bahwa guru tidak ada kendala dalam menerapkan model Pembelajaran Berbasis Masalah 
(PBM), guru sudah mampu menerapkan model Pembelajaran Berbasis Masalah (PBM) dengan baik sesuai dengan langkah-langkahnya dan dapat membuat permasalahan yang akan jadi bahan penyelidikan yanga terdapat pada lembar kerja siswa |(LKS). Hasil jawaban guru tersebut berbeda ketika hasil wawancara sebelum dilakukan penelitian rata-rata guru masih kesulitan dalam menerapkan model Pembelajaran Berbasis Masalah (PBM) dengan baik sesuai dengan langkahlangkahnya dan belum terampil membuat permasalahan yang akan jadi bahan penyelidikan yanga terdapat pada lembar kerja siswa |(LKS).

Hasil perbandingan rata-rata aktiftas guru dan aktifitas kepala sekolah pada tindakan siklus 1 dan 2 dapat dijelaskan pada tabel 14 sebagai berikut.

Tabel 14 Perbandingan hasil penilaian aktifitas kepala sekolah dan guru siklus 1 dan 2

\begin{tabular}{crcccc}
\hline \multirow{2}{*}{ No } & \multirow{2}{*}{ Aspek penilaian } & \multicolumn{2}{c}{ Siklus 1 } & \multicolumn{2}{c}{ Siklus 2 } \\
\cline { 2 - 5 } & Rerata & Kriteria & Rerata & Kriteria \\
\hline 1 & $\begin{array}{l}\text { Aktifitas kepala } \\
\text { sekolah }\end{array}$ & 83 & Sangat baik & 93 & $\begin{array}{l}\text { Sangat } \\
\text { baik }\end{array}$ \\
\hline 2 & Aktifitas guru & 70 & Cukup baik & 90 & $\begin{array}{l}\text { Sangat } \\
\text { baik }\end{array}$ \\
\hline
\end{tabular}

Dari hasil observasi terhadap aktifitas kepala sekolah dan aktifitas guru seperti pada tabel 14 diatas dapat dijelaskan bahwa penerapan SGD sangat berdampak positif bagi pelaksanaan tindakan yang dilakukan kepala sekolah. Dampak positif tersebut ditandai dengan meningkatnya hasil penilaian aktiftas kepala sekolah pada tindakan siklus sebesar 83 dengan kriteria sangat baik menjadi 93 dengan kriteria sangat baik. Hasil penilaian aktifitas guru juga mengalami peningkatan dari hasil penilaian aktiftas guru pada tindakan siklus 1 rata-rata 70 dengan kriteria cukup baik, pada tindakan siklus 2 menjadi 90 dengan kriteria sangat baik.

Perbandingan dari 2 aspek penilaian produk guru dan hasil penilaian praktek pembelajaran di kelas sebelum dilakukan penelitian dan hasil penilaian pada siklus 1 dan siklus 2 dapat dijelaskan pada tabel 15 sebagai berikut. 
Tabel 15 Perbandingan hasil penilaian produk guru (RPP) dan praktek pembelajaran di kelas, sebelum dilakukan penelitian

dan hasil penelitian siklus 1 dan siklus 2

\begin{tabular}{cccccccc}
\hline No & $\begin{array}{c}\text { Aspek } \\
\text { penilaian }\end{array}$ & Sebelum penelitian & \multicolumn{2}{c}{ Siklus 1 } & \multicolumn{2}{c}{ Siklus 2 } \\
\cline { 2 - 7 } & Rerata & Kriteria & Rerata & Kriteria & Rerata & Kriteria \\
\hline 1 & $\begin{array}{l}\text { Produk guru } \\
\text { (RPP) }\end{array}$ & 56 & $\begin{array}{l}\text { Kurang } \\
\text { baik }\end{array}$ & 78 & Baik & 89 & $\begin{array}{c}\text { Sangat } \\
\text { baik }\end{array}$ \\
\hline 2 & $\begin{array}{l}\text { Praktek } \\
\text { pembelajaran } \\
\text { di kelas }\end{array}$ & 59 & $\begin{array}{l}\text { Kurang } \\
\text { baik }\end{array}$ & 83 & $\begin{array}{l}\text { Sangat } \\
\text { baik }\end{array}$ & 89 & $\begin{array}{c}\text { Sangat } \\
\text { baik }\end{array}$ \\
\hline
\end{tabular}

Dari hasil perbandingan penilaian dari 2 aspek seperti pada tabel 15 diatas dapat disimpulkan bahwa bahwa penerapan metode small group discussion (SGD) berhasil meningkatkan pemahaman tentang Pembelajaran Berbasis Masalah Matematika. Peningkatan pemahaman guru ini ditandai dengan meningkatnya hasil penilaian terhadap produk guru berupa rencana pelaksanaan pembelajaran (RPP) dengan menggunakan model Pembelajaran Berbasis Masalah, dari sebelum penelitian rata-rata 56 dengan kriteria kurang baik, pada tindakan siklus 1 menjadi 78 dengan kriteria baik dan siklus 2 menjadi 89 dengan kriteria sangat baik. Sedangkan peningkatan pada penilaian praktek pembelajaran di kelas pada pelajaran matematika dengan menggunakan model Pembelajaran Berbasis Masalah dari sebelum penelitian rata-rata 59 dengan kriteria kurang baik, pada tindakan siklus 1 menjadi 83 dengan kriteria sangat baik dan siklus 2 sebesar 89 dengan kriteria sangat baik.

Penerapan PBL dengan metode SGD memberikan kesempatan kepada guru untuk memperoleh kemampuan bersosialisasi seperti komunikasi, kerja sama, dan pemahaman materi lebih cepat (Muhtarom \& Kurniasih, 2020). Kelompok dalam PBL adalah kelompok diskusi kecil (small group discussion(SGD) yang terdiri dari 10-12 orang, difasilitasi oleh guru sebagai fasilitator. Masalah yang diajukan berguna sebagai perangsang siswa untuk melakukan diskusi tentang upaya memahami dan memecahkan masalah tersebut. Sebagai tujuan akhir siswa 
akan terbiasa memahami dan mampu menyelesaaikan masalah kehidupan seharihari. Terdapat beberapa faktor yang mempengaruhi proses pembelajaran PBL yaitu: faktor siswa, guru, fasilitas, proses pembelajaran, isi pembelajaran dan penjadwalan (Lestarini \& Suriana, 2018). PBL dengan metode SGD memberikan kesempatan kepada siswa untuk memgidentifikasi masalah, menyelesaaikan tantangan, menjadi model, mengaktifkan siswa, dan mengevaluasi hasil pembelajaran

\section{SIMPULAN}

Berdasarkan permasalahan yang dikaji dari studi pendahuluan pada penelitian ini maka dapat diambil kesimpulan bahwa tindakan kepala sekolah dengan menggunakan metode small group discussion (SGD) sangat efektif sebagai sarana diskusi dan tukar pendapat guna untuk meningkatkan pengetahuan dan pemahaman guru tentang Pembelajaran Berbasis Masalah Matematika di SDN Gunungsari 1 kecamatan Maesan kabupaten Bondowoso. Tindakan kepala sekolah dengan menggunakan metode small group discussion (SGD) dapat meningkatkan pemahaman guru tentang Pembelajaran Berbasis Masalah Matematika di SDN Gunungsari 1 kecamatan Maesan kabupaten Bondowoso. Untuk meningkatkan kemampuan guru di dalam menerapkan Pembelajaran Berbasis Masalah matematika hendaknya guru juga harus memperhatikan media pembelajaran yang digunakan dalam pemecahan masalah tersebut.

\section{DAFTAR RUJUKAN}

Arta, I., Japa, I. G. N., \& Sudarma, I. K. (2020). Problem Based Learning Berbantuan Icebreaker Berpengaruh Terhadap Kemampuan Pemecahan Masalah Matematika. Mimbar PGSD Undiksha, 8(2), 264-272.

Elita, G. S., Habibi, M., Putra, A., \& Ulandari, N. (2019). Pengaruh Pembelajaran Problem Based Learning dengan Pendekatan Metakognisi terhadap Kemampuan Pemecahan Masalah Matematis. Mosharafa: Jurnal Pendidikan Matematika, 8(3), 447-458. Retrieved from http://journal.institutpendidikan.ac.id/index.php/mosharafa Fitria, N., Hernawati, T., \& Oktavia Hidayati, N. (2013). Adversity Quotient Mahasiswa Baru yang Mengikuti Kurikulum Berbasis Kompetensi. Jurnal 
Keperawatan Padjadjaran, 1(2), 99-105.

https://doi.org/10.24198/jkp.v1n2.5

Lestarini, A., \& Suriana, S. N. (2018). Optimalisasi Peran Fasilitator untuk

Meningkatkan Keefektifan Diskusi Kelompok pada Blok Musculoskeletal

System and Disorders. WMJ (Warmadewa Medical Journal), 2(2), 52.

https://doi.org/10.22225/wmj.2.2.373.52-59

Mawaddah, S., \& Anisah, H. (2015). Kemampuan Pemecahan Masalah Matematis

Siswa Pada Pembelajaran Matematika Dengan Menggunakan Model

Pembelajaran Generatif (Generative Learning) Di SMP. EDU-MAT: Jurnal

Pendidikan Matematika, 3(2), 166-175.

https://doi.org/10.20527/edumat.v3i2.644

Muhtarom, H., \& Kurniasih, D. (2020). Pengaruh Model Pembelajaran Abad 21

Terhadap Pembelajaran Sejarah Eropa. Bihari: Pendidikan Sejarah Dan Ilmu Sejarah, 3(2), 59-65.

Sari, D. N. A. (2017). Penerapan Kurikulum Berbasis Kompetensi (KBK) Dengan Small Group Discussion (SGD) Untuk Mengukur Kognitif Pada Mahasiswa.

Jurnal Kesehatan Karya Husada, 5(1), 1-29.

https://doi.org/https://doi.org/10.36577/jkkh.v5i1.87

Sukirman, \& Hidayati, D. (2020). Kesiapan Mental Guru Muhammadiyah.

JURNAL ADMINISTRASI PENDIDIKAN, 27(2), 252-357.

https://doi.org/https://doi.org/10.17509/jap.v27i2.26422

Surur, M., \& Tartilla, T. (2019). Pengaruh Problem Based Learning Dan Motivasi Berprestasi Terhadap Kemampuan Pemecahan Masalah. Indonesian Journal of Learning Education and Counseling, 1(2), 169-176.

https://doi.org/10.31960/ijolec.v1i2.96

Tyas, R. (2017). Kesulitan Penerapan Problem Based Learning Dalam

Pembelajaran Matematika. Tecnoscienza, 2(1), 43-52. 